\title{
Abundance and foraging behaviour of major insect pollinators on seed crop of broccol (Brassica oleracea L. var. italica Plenck) LPH-1
}

\author{
Suman Devi" ${ }^{* 1}$, Ombir ${ }^{1}$, Sumit $^{2}$ and Yashdev Singh ${ }^{1}$ \\ ${ }^{1}$ Department of Entomology, CCS Haryana Agricultural University, Hisar-125004 (Haryana), INDIA \\ ${ }^{2}$ Department of Agricultural Economics, CCS Haryana Agricultural University, Hisar-125004 (Haryana), INDIA \\ *Corresponding author. E-mail: narwal_suman@yahoo.in
}

Received: November 09, 2015; Revised received: June 02, 2016; Accepted: August 07, 2016

\begin{abstract}
The studies were carried out at the Vegetable Research Farm, CCS Haryana Agricultural University, Hisar during 2013-2014. The main aim of the study was good seed setting and it is done by bee pollination which improves the yield and quality of crops. The results shows revealed that Apis mellifera (5.96) was the most abundant visitor and highly significant over $A$. florea (4.46), syrphid fly (2.97), A.dorsata (2.62) and A.cerana (1.66) visitor. Irrespective of species, abundance of bees was the lowest at $0700-0900 \mathrm{~h}\left(0.73 \mathrm{bees} / \mathrm{m}^{2} / 5 \mathrm{minutes}\right)$ and the highest at $1100-1300 \mathrm{~h}\left(6.29 \mathrm{bees} / \mathrm{m}^{2} / 5\right.$ minutes). The result of foraging speed, maximum for $A$. florea (37.44) and highly significant over followed by $A$. dorsata (5.24), A. mellifera (4.52), A. cerana (3.58) and syrphid fly (2.67). The result of foraging rate, maximum for syrphid fly (17.42) and highly significant over $A$. cerana (10.27), A. mellifera (10.00), A. dorsata (7.77) and $A$. florea (1.71). Due to bee pollination, seed set in caged condition was very less as compared to uncaged condition and quality of seeds was also good in uncaged condition.
\end{abstract}

Keywords: Abundance, Broccoli, Foraging behavior, Honey bee

\section{INTRODUCTION}

Broccoli is cross pollinated and grown by seed and insect play major role in pollination. The flowers of broccoli, important sources for both pollen and nectar, are very attractive to honeybees. Among the total pollination activities, over $80 \%$ is performed by insects and bees contribute nearly $80 \%$ of the total insect pollination and therefore, they are considered the best pollinators. Bee pollination improves the yield and quality of crops, such as fruits, vegetable seeds, spices, oilseeds and forage crops (Dhakal, 2003; NARC, 2008). The number of flowers visited per minute by any type of bee species depends upon the number of factors including instinctive foraging behaviour, length of proboscis, floral structure particularly the corolla depth type and quantity of floral rewards density of flowers on particular cultivar of the crop concerned and hours of the day. Foraging behavior play an important role on the production and productivity of the crops which is use to compare pollination efficiency of different honeybee species. More foraging frequency indicated the more pollination efficiency (Singh et. al. 2006). Devkota and Thapa (2005) studied that two bee species (A. cerana and A. mellifera) differed significantaly $(\mathrm{P}<0.05)$ on the number of flower visits per minut on broccoli. A. cerana showed higher flower visiting efficiency as compared to A. mellifera. The average number of flower visited by A. cerana bee was 11.387 and 12.107 per minute as compared to 9.033 and 10.889 flower per minute by A. mellifera under caged and open conditions respectively. There is very scanty information available for the role of insect pollinators and their efficiency in seed production of broccoli under agro-climatic conditions of Haryana. So, study was undertaken to record the abundance and forging behavior of major insect pollinators especially honey bees and syrphid fly on seed crop of broccoli.

\section{MATERIALS AND METHODS}

The studies were carried out at the Vegetable Research Farm, CCS Haryana Agricultural University, Hisar during 2013-2014. Broccoli variety LPH-1 was grown for seed production. Flowering initiated during $2^{\text {nd }}$ week of March, peak period between $3^{\text {rd }}-4^{\text {th }}$ week and cessation in the last week of March.

Abundance of insect visitors/pollinators on broccoli flowers: Abundance of major insect visitors/ pollinators on broccoli flowers was recorded during the blooming period of the crop. For recording these observations, numbers of pollinators visiting per square meter area of crop $/ 5$ minutes were noted from five randomly selected areas. These observations were recorded from $0700 \mathrm{~h}$ to $1900 \mathrm{~h}$ at an interval of 2:00 hours. Observations were recorded throughout the flowering season in the crop.

Determination of the foraging speed of insect pollinators: Foraging speed of bees was recorded in terms of time (seconds) spent by them on each flower (Free, 1993). A total of ten bees of each species were ob- 
served for recording time spent by them per flower at peak flowering period of the crop. The time spent to inject the proboscis and suck up the nectar or brushing/ collecting pollens was considered as the time spent per flower, which was recorded with the help of a chonometer having an accuracy of 0.01 seconds (Kumar, 2010). Ten observations were recorded for each bee species.

Determination of the foraging rate of insect pollinators: Foraging rate of bees was recorded in terms of the number of flowers they visited per minute (Free, 1993). A total of ten bees of each species were observed for recording the number of flowers visited per minute at peak activity time of particular species at peak flowering period of the crop. The numbers of flowers visited per minute were recorded including the flying time from one flower to another flower (Kumar, 2010). Ten observations were recorded for each bee species.

\section{RESULTS AND DISCUSSION}

Abundance: Data on abundance (irrespective of flowering stage of crop) of different species of seed crop of broccoli variety LPH-1 at different hours of the day are presented in Table 1. The mean population of bee species over different day hours ranged from 1.66 (A. cerana) to 5.96 bees $/ \mathrm{m}^{2} / 5$ minutes (A. mellifera). For $A$. mellifera, the maximum bee population was observed at $1100-1300 \mathrm{~h}\left(10.87 \mathrm{bees} / \mathrm{m}^{2} / 5\right.$ minutes $)$, followed by $1300-1500 \mathrm{~h}$ (10.53 bees $/ \mathrm{m}^{2} / 5$ minutes $), 1500-1700 \mathrm{~h}$ (5.27 bees $/ \mathrm{m}^{2} / 5$ minutes), $0900-1100 \mathrm{~h}\left(5.20\right.$ bees $/ \mathrm{m}^{2} / 5$ minutes), $1700-1900 \mathrm{~h}$ ( 2.87 bees $/ \mathrm{m}^{2} / 5$ minutes $)$ and 0700-0900 h (1.01 bees $/ \mathrm{m}^{2} / 5$ minutes). Irrespective of species, abundance of bees was the lowest at 0700$0900 \mathrm{~h}\left(0.73\right.$ bees $/ \mathrm{m}^{2} / 5$ minutes $)$ and the highest at $1100-1300 \mathrm{~h}\left(6.29 \mathrm{bees} / \mathrm{m}^{2} / 5\right.$ minutes $)$. The cumulative mean abundance of important species revealed that $A$. mellifera (5.96) was the most abundant visitor fol- lowed by A. florea (4.46), syrphid fly (2.97), A. dorsata (2.62) and $A$. cerana (1.66) was least frequent visitor. Pritish (2012) found that the abundance of $A$. mellifera ( 6.8 bees $/ \mathrm{m}^{2} / 5$ minutes)was highest followed by $A$. florea ( 5.1 bees $/ \mathrm{m}^{2} / 5$ minutes), syrphid fly (4.8 flies $/ \mathrm{m}^{2} / 5$ minutes), A. dorsata ( 3.5 bees $/ \mathrm{m}^{2} / 5$ minutes) and $A$. cerana ( 1.4 bees $/ \mathrm{m}^{2} / 5$ minutes) in radish. Irrespective of species, the population was maximum $(6.5$ bees $/ \mathrm{m}^{2} / 5$ minutes) at $1100-1300 \mathrm{~h}$ of the day.

Foraging rate: Data on foraging rate of different honey bee species on broccoli flowers of variety LPH1 are presented in Table 2 . The highest foraging rate (no. of flowers visited/minute) was of syrphid fly (18.54) followed by A. cerana (12.67), A. mellifera (12.07), A. dorsata (10.55) and A. florea (1.89). Mean maximum foraging rate of syrphid fly, A. cerana, $A$. mellifera, A. dorsata, and A. florea was observed during 1500-1700, 1100-1300, 1300-1500, 1100-1300 and 0900-1100 $\mathrm{h}$ of the day, respectively. Mean foraging rate of syrphid fly during peak flowering was observed maximum (17.42) followed by A. cerana (10.27), A. mellifera (10.00), A. dorsata (7.77) and A. florea (1.71). Mean foraging rate irrespective of honey bee species during different day hours was maximum between 1100-1300h (10.74) and minimum between 1700-1900h (7.31). Pritish (2012) reported that mean foraging rate of $A$. cerana during peak flowering was observed maximum (10.3 no. of flowers visited/ minute) followed by $A$. mellifera $(9.8$ no. of flowers visited/minute), A. dorsata (9.5 no. of flowers visited/ minute), and A. florea (8.9 no. of flowers visited/ minute). Devkota and Thapa (2005) studied that two bee species (A. cerana and A. mellifera) differed significantaly $(\mathrm{P}<0.05)$ on the number of flower visits per minute on broccoli. A. cerana showed higher flower visiting efficiency as compared to A. mellifera. The

Table 1. Diurnal abundance (irrespective of flowering stage of crop) of major insect pollinators on blossoms on seed crop of broccoli variety LPH-1 during March, 2014.

\begin{tabular}{|c|c|c|c|c|c|c|c|}
\hline \multirow{2}{*}{ Species } & \multicolumn{6}{|c|}{ Number of bees $/ \mathrm{m}^{2} / 5$ minutes during different day hours } & \multirow[b]{2}{*}{ Mean } \\
\hline & 0700-0900 & 0900-1100 & 1100-1300 & $1300-1500$ & $1500-1700$ & 1700-1900 & \\
\hline \multirow{2}{*}{ Apis mellifera } & 1.01 & 5.20 & 10.87 & 10.53 & 5.27 & 2.87 & 5.96 \\
\hline & (1.41) & $(2.49)$ & $(3.43)$ & (3.38) & $(2.51)$ & (1.97) & $(2.53)$ \\
\hline \multirow{2}{*}{ Apis dorsata } & 1.89 & 2.40 & 3.13 & 3.57 & 2.73 & 1.97 & 2.62 \\
\hline & (1.68) & (1.85) & (2.03) & $(2.11)$ & $(1.92)$ & (1.71) & $(1.88)$ \\
\hline \multirow{2}{*}{ Apis cerana } & 0.27 & 2.00 & 2.60 & 2.57 & 2.03 & 0.50 & 1.66 \\
\hline & (1.13) & $(1.73)$ & (1.90) & (1.88) & $(1.72)$ & (1.22) & $(1.60)$ \\
\hline \multirow{2}{*}{ Apis florea } & 0.05 & 2.50 & 9.93 & 9.03 & 4.20 & 1.07 & 4.46 \\
\hline & (1.03) & $(1.85)$ & (3.24) & (3.10) & $(2.25)$ & (1.40) & $(2.14)$ \\
\hline \multirow{2}{*}{ Syrphid fly } & 0.41 & 3.30 & 4.90 & 4.50 & 3.43 & 1.30 & 2.97 \\
\hline & (1.17) & $(2.05)$ & $(2.40)$ & $(2.31)$ & $(2.08)$ & (1.51) & $(1.92)$ \\
\hline \multirow{2}{*}{ Mean } & 0.73 & 3.08 & 6.29 & 6.04 & 3.53 & 1.54 & \\
\hline & $(1.28)$ & $(1.99)$ & $(2.60)$ & $(2.56)$ & $(2.09)$ & $(1.56)$ & \\
\hline Factors & & & $\mathrm{SE}(\mathrm{m})$ & $\overline{\mathrm{SE}(\mathrm{d})}$ & & C.D. $(p=0.05)$ & \\
\hline Species & & & 0.006 & 0.008 & & 0.016 & \\
\hline Day hours & & & 0.006 & 0.009 & & 0.018 & \\
\hline Species X day hours & & & 0.014 & 0.020 & & 0.040 & \\
\hline
\end{tabular}

Each value represents mean of 5 observations at each sampling time; Figures in parentheses are $\sqrt{ }(x+1)$ transformed values 
Suman Devi et al. / J. Appl. \& Nat. Sci. 8 (3): 1493 - 1496 (2016)

Table 2. Foraging rate of different honey bee species on broccoli flowers of variety LPH-1 at different hours of the day during March, 2014.

\begin{tabular}{|c|c|c|c|c|c|c|}
\hline \multirow{2}{*}{ Species } & \multicolumn{4}{|c|}{ Number of flower visited per minute } & \multirow[b]{2}{*}{$1700-1900$} & \multirow[b]{2}{*}{ Mean } \\
\hline & 0900-1100 & $1100-1300$ & $1300-1500$ & $1500-1700$ & & \\
\hline \multirow{2}{*}{ Apis mellifera } & 10.52 & 11.47 & 12.07 & 9.74 & 6.18 & 10.00 \\
\hline & $(3.39)$ & $(3.53)$ & $(3.61)$ & $(3.26)$ & $(2.67)$ & $(3.29)$ \\
\hline \multirow{2}{*}{ Apis dorsata } & 9.17 & 10.55 & 7.27 & 6.60 & 5.27 & 7.77 \\
\hline & $(3.17)$ & $(3.38)$ & $(2.86)$ & $(2.74)$ & $(2.50)$ & $(2.93)$ \\
\hline \multirow{2}{*}{ Apis cerana } & 10.64 & 12.67 & 10.17 & 10.48 & 7.41 & 10.27 \\
\hline & $(3.40)$ & $(3.69)$ & $(3.34)$ & $(3.38)$ & $(2.88)$ & $(3.34)$ \\
\hline \multirow{2}{*}{ Apis florae } & 1.89 & 1.74 & 1.77 & 1.78 & 1.35 & 1.71 \\
\hline & (1.69) & (1.63) & $(1.65)$ & (1.64) & $(1.52)$ & $(1.63)$ \\
\hline \multirow[t]{2}{*}{ Syrphid fly } & 17.91 & 17.30 & 16.98 & 18.54 & 16.35 & 17.42 \\
\hline & $(4.34)$ & $(4.26)$ & $(4.24)$ & $(4.41)$ & $(4.16)$ & $(4.28)$ \\
\hline \multirow[t]{2}{*}{ Mean } & 10.03 & 10.74 & 9.65 & 9.43 & 7.31 & \\
\hline & $(3.20)$ & $(3.30)$ & $(3.14)$ & $(3.09)$ & $(2.75)$ & \\
\hline Factors & & $\mathrm{SE}(\mathrm{m})$ & \multicolumn{2}{|c|}{ SE(d) } & \multicolumn{2}{|c|}{ C.D. $(p=0.05)$} \\
\hline Species & & 0.039 & \multicolumn{2}{|c|}{0.055} & \multicolumn{2}{|c|}{0.106} \\
\hline Day hours & & 0.038 & \multicolumn{2}{|c|}{0.054} & \multicolumn{2}{|c|}{0.108} \\
\hline Species x Day hours & & 0.086 & \multicolumn{2}{|c|}{0.121} & \multicolumn{2}{|c|}{0.240} \\
\hline
\end{tabular}

Each value represents mean of 10 observations at each sampling time; Figures in parentheses are $\sqrt{ }(x+1)$ transformed values

Table 3. Foraging speed of different honey bee species on broccoli flowers of variety LPH-1 at different hours of the day during March, 2014.

\begin{tabular}{|c|c|c|c|c|c|c|}
\hline \multirow{2}{*}{ Species } & \multicolumn{5}{|c|}{ Time spent per flower (sec) } & \multirow[b]{2}{*}{ Mean } \\
\hline & 0900-1100 & 1100-1300 & $1300-1500$ & $1500-1700$ & 1700-1900 & \\
\hline \multirow{2}{*}{ Apis mellifera } & 3.92 & 3.72 & 4.08 & 5.57 & 5.30 & 4.52 \\
\hline & $(2.21)$ & $(2.16)$ & $(2.24)$ & $(2.55)$ & $(2.48)$ & $(2.33)$ \\
\hline \multirow{2}{*}{ Apis dorsata } & 5.21 & 4.72 & 4.65 & 6.11 & 5.48 & 5.24 \\
\hline & $(2.49)$ & $(2.38)$ & $(2.37)$ & $(2.66)$ & $(2.53)$ & $(2.49)$ \\
\hline \multirow{2}{*}{ Apis cerana } & 3.70 & 2.68 & 2.58 & 4.65 & 4.31 & 3.58 \\
\hline & $(2.16)$ & (1.91) & (1.89) & $(2.36)$ & $(2.29)$ & $(2.12)$ \\
\hline \multirow{2}{*}{ Apis florae } & 29.61 & 38.40 & 33.58 & 42.88 & 42.71 & 37.44 \\
\hline & $(5.41)$ & $(6.21)$ & $(5.76)$ & $(6.52)$ & $(6.56)$ & $(6.09)$ \\
\hline \multirow[t]{2}{*}{ Syrphid fly } & 2.32 & 2.47 & 2.65 & 2.24 & 3.67 & 2.67 \\
\hline & $(1.82)$ & $(1.85)$ & $(1.90)$ & $(1.79)$ & $(2.14)$ & $(1.90)$ \\
\hline \multirow[t]{2}{*}{ Mean } & 8.95 & 10.40 & 9.51 & 12.29 & 12.30 & \\
\hline & $(2.82)$ & $(2.90)$ & $(2.83)$ & $(3.18)$ & $(3.20)$ & \\
\hline \multirow{2}{*}{\multicolumn{2}{|c|}{$\begin{array}{l}\text { Factors } \\
\text { Species }\end{array}$}} & \multicolumn{2}{|c|}{ SE(m) } & SE(d) & \multicolumn{2}{|c|}{ C.D. $(p=0.05)$} \\
\hline & & \multirow{2}{*}{\multicolumn{2}{|c|}{$\begin{array}{l}0.090 \\
0.090\end{array}$}} & 0.127 & \multicolumn{2}{|c|}{0.251} \\
\hline \multicolumn{2}{|l|}{ Day hours } & \multirow{2}{*}{\multicolumn{2}{|c|}{$\begin{array}{l}0.090 \\
0201\end{array}$}} & 0.127 & \multicolumn{2}{|c|}{0.251} \\
\hline Species x Day hours & & & & 0.284 & \multicolumn{2}{|c|}{ NS } \\
\hline
\end{tabular}

Each value represents mean of 10 observations at each sampling time; Figures in parentheses are $\sqrt{ }(x+1)$ transformed values

average number of flower visited by A. cerana bee was 11.387 and 12.107 per minute as compared to 9.033 and 10.889 flower per minute by $A$. mellifera under caged and open conditions respectively.

Foraging speed: Data on foraging speed (time spent per flower) of different honey bee species during different day hours on flowers of broccol seed variety $\mathrm{GH}$ -1 crop are presented in table 3 . The highest foraging speed was of $A$. florea (44.70) followed by $A$. dorsata (6.05), A. mellifera (5.64), A. cerana (4.71) and syrphid fly (3.50). Mean maximum foraging speed of $A$. florea, A. dorsata, A. mellifera, A. cerana and syrphid fly was observed during 1700-1900, 1500-1700, 1500$1700,1500-1700$ and $1700-1900 \mathrm{~h}$ of the day respectively. Foraging speed of $A$. florea during peak flowering irrespective of day hours was observed maximum (38.54) followed by A. dorsata (5.24), A. mellifera
(4.54), and A. cerana (3.51) and syrphid fly (2.65). Foraging speed of honey bee species during different day hours was observed maximum between 1700$1900 \mathrm{~h}$ (12.62) and minimum between 0900-1100h (9.02). Thakur et al. (2004) recorded that A. mellifera was the most frequent visitor of broccoli followed by Helictus sp. and A. cerana. Although Bombus trifasciatus was the most active spent minimum time per flower (1.95 seconds), its population was less compared to honey bees and Helictus sp. and hence ranked fourth. The syrphid fly, Eristalis tenax ranked last among the top 5 positions.

\section{Conclusion}

The results shows that mean abundance of important species revealed that Apis mellifera (5.96) was the most abundant and highly significant visitor followed 
by A. florea (4.46), syrphid fly (2.97), A.dorsata (2.62) and $A$. cerana was least frequent (1.66) visitor. In case of mean foraging speed, maximum foraging speed of A. florea (37.44) and which is highly significant over A. dorsata (5.24), A. mellifera (4.52), A. cerana (3.58) and syrphid fly (2.67). Foraging rate of syrphid fly (17.42) was maximum and highly significant over $A$. cerana (10.27), A. mellifera (10.00), A. dorsata (7.77) and $A$. florea (1.71). It was found that due to bee pollination the number of siliqua, seeds in each siliqua, siliqua length, germination percentage and vigour was found maximum as compared to caged condition.

\section{REFERENCES}

Devkota, F.R. and Thapa, R.B. (2005). Foraging preferance of Apis cerana $\mathrm{F}$. and Apis mellifera $\mathrm{L}$. to broccoli under caged and open conditions. Journal of the Institute of Agriculture and Animal Science. 26: 167-168.

Dhakal, G.C. (2003). A comparative study of Apis cerana F. and Apis mellifera L. on pollination of Brassica campestris Var.toria and Fagopyrum esculentum M. at Rampur, Chitwan. M. Sc. In Entomology Thesis TU.
IAAS Rampur, Chitwan, Nepal. pp 76.

Free, J.B. (1993). Insect pollination of Crops (2nd edn.). Academic Press, London, U.K. pp 684. Kumar, B.K. (2010). Studies on insect pollinators on bitter gourd (Momordica charantia L.) M. Sc. Thesis, Department of Entomology, Chaudhary Charan Singh Haryana Agricultural University, Hisar. pp 21.

NARC (2008). Introduction of trained bees, Apis mellifera L. for quality seed and higher seed on mustard, Brassica campestris Var. toria in Nepalese condition. Annual Technical Report 2006- 2007.Entomology Division, Nepal Agriculture Research Council. Khumaltar, Lalitpur, Nepal. pp. 27-32.

Pritish, J. (2012). Studies on insect pollinators on seed crop of radish (Raphanus sativus L.). M. Sc.Thesis, Department of Entomology, Chaudhary Charan Singh Har ana AgriculturalUniversity, Hisar. pp 12-42.

Singh, J., Agarwal, O.P. and Mishra, R.C. (2006) Foraging rates of different Apis species visiting parental lines of Brassica napus L. Zoos' print journal. 21: 2226-2227.

Thakur, S.S., Sanjeev and Verma K.S. (2004). Bloom visiting insects and their foraging behaviour on broccoli. Pest Management Economic Zoology. 12 (2): 145-151. 